\title{
YELLOW ROWS OF TEST TUBES: DUE PROCESS CONSTRAINTS ON DISCHARGES OF PUBLIC EMPLOYEES BASED ON DRUG URINALYSIS TESTING
}

\author{
Danel P. Mazo $\dagger$
}

As the problem of employee drug abuse gains increasing attention from the popular ${ }^{1}$ and business ${ }^{2}$ news media, many public and private employers have instituted medical testing programs to detect drug use among employees. ${ }^{3}$ In the public sector, large-scale drug screening began in the United States military in $1981 .^{4}$ Currently, agencies at all levels of government have testing programs;, moreover, on September 15, 1986, President Reagan signed Executive Order 12,564 mandating a drug-free federal workplace and requiring the head of each executive agency to establish a drug testing program within the parameters of the executive order. ${ }^{6}$ This order is estimated to affect more than one million federal employees. ${ }^{7}$ Clearly, drug testing is an issue many public employees now or will soon face.

Drug testing is usually carried out by urinalysis, the easiest and least expensive method. ${ }^{8}$ However, drug urinalysis testing has generated much opposition, primarily on the ground that it violates the privacy rights of the persons tested. ${ }^{\ominus}$ This Comment focuses on testing of

† B.A. 1985, University of Virginia; J.D. Candidate 1988, University of Pennsylvania.

1 See Weisman, 48 Hours on Crack Street: I Was a Drug-Hype Junkie, New REPuBlic, Oct. 6, 1986, at 14, 15 (describing plethora of feature stories on drug abuse in major weekly news magazines).

${ }^{2}$ See Hosty \& Elliott, Drug Abuse in Industry: What Does it Cost and What Can Be Done?, Security MGMT., Oct. 1985, at 53, 55 (discussing the costs of drug abuse to industry); Klein, Employees Under the Influence-Outside the Law?, PERSONNEL J., Sept. 1986, at 57, 59-60 (discussing employer tort liability for the actions of intoxicated employees).

3 See Note, Drug Testing in the Workplace: A Legislative Proposal to Protect Privacy, 13 J. LeGis. 269, 270-72 (1986).

4 Stille, Drug Testing: The Scene is Set for a Dramatic Legal Collision Between the Rights of Employers and Workers, Nat'l L.J., Apr. 7, 1986, at 1, col. 1.

${ }_{3}$ See infra notes 27-29 and accompanying text (court challenges to drug testing of state and local government employees); note 41 (same for federal employees).

- Exec. Order No. 12,564, 3 C.F.R. 224 (1987).

? See, e.g., A Question of Privacy, Drug Tests Raise a Host of Constitutional Issues, Newsweek, Sept. 29, 1986, at 18.

B See M. Rothstein, Medical Screening of Workers 70-71 (1984) (discussing the expense and frequency of urine tests for marijuana usage).

- See, e.g., National Treasury Employees Union v. von Raab, 649 F. Supp. 380, 389 (E.D. La. 1986) (drug testing plan violates penumbral privacy rights granted by 
public employees, who are. subject to the protections of the United States Constitution under the state action doctrine. ${ }^{10}$ Legal challenges to public sector testing programs alleging that testing violates the constitutional guarantee against unreasonable searches and seizures ${ }^{11}$ have been successful in several employment contexts. ${ }^{12}$ Such challenges usually are resolved by balancing the individual's interest in privacy against the public interest in having an unimpaired public workforce. ${ }^{13}$ The emerging judicial consensus is that a public employee may be compelled to submit a urine sample when there are reasonable grounds to suspect that she is using illegal drugs. ${ }^{14}$ In addition, some courts have held that the sensitive nature of an employee's occupation can severely diminish her reasonable expectation of privacy. ${ }^{15}$

But the legal problems raised by drug testing do not end with the question of whether or not an employer can test. Many, if not most, public employees have recognized "property" rights in their jobs. ${ }^{16}$ Some courts also recognize a liberty interest in one's reputation that can be damaged by the reporting of a positive drug test result. ${ }^{17}$ In general, a public employer cannot deprive its employees of these rights without due process of law. ${ }^{18}$ Therefore, even where drug testing is found to be "reasonable" in light of some state interest, there remains an issue of whether an employer's actions in response to positive test results are consistent with the employee's constitutional due process rights.

This Comment argues that the procedural protections presently available to most public employees who are subject to drug testing are

the Constitution), vacated, 816 F.2d 170 (5th Cir. 1987).

${ }^{10}$ Constitutional freedoms are effective against government agencies, as well as some private entities acting under state authority; see $2 \mathrm{R}$. RotUNDA, J. NowAK \& J. Young, Treatise on Constitutional Law: Substance and Procedure $§ 16.3$, at 171-79 (1986) (describing "state action" doctrine). Some of the constitutional issues discussed in this Comment are relevant to private sector employees who are tested for drug use under color of state or federal law. See, e.g., Shoemaker v. Handel, 795 F.2d 1136,1138 (3d Cir.) (jockeys at private tracks subject to testing by state racing commission), cert. denied, 107 S. Ct. 577 (1986); 49 C.F.R. § 219 (1986) (Federal Railroad Administration authorizes railroads to test employees as means of enforcing federal safety standards).

11 U.S. CoNST. amend. IV.

12 See infra notes 27-32 and accompanying text.

1s See, e.g., Division 241 Amalgamated Transit Union v. Suscy, 538 F.2d 1264, 1267 (7th Cir.), cert. denied, 429 U.S. 1029 (1976) (finding that the interest in protecting the public by ensuring that bus and train operators are fit to perform their jobs outweighs the employees' privacy interest when testing is done only following accidents or on suspicion of drug or alcohol use).

14 See infra notes 24-32 and accompanying text.

15 See infra notes 34-51 and accompanying text.

${ }_{18}$ See infra notes 87-98 and accompanying text.

17 See infra notes $99-108$ and accompanying text.

18 See infra notes $97-99$ and accompanying text. 
constitutionally inadequate. Part I discusses the legality of drug testing based on a fourth amendment analysis, with particular attention to current testing programs in the federal government. Part II outlines the public employee's property and liberty interests upon which drug testing programs may infringe, and frames the issue of what process is due the drug-tested employee in terms of the Supreme Court's three-part balancing test in Mathews v. Eldridge. ${ }^{19}$ Part II also considers the Court's rejection of positivist due process analysis in Cleveland Board of Education v. Loudermill. ${ }^{20}$ Part III discusses the unreliability of available testing methods and the employee's interest in avoiding being falsely branded a drug abuser, and proposes more stringent procedural requirements than have previously been recognized for employer actions based on positive employee drug test results.

\section{The legality of Drug Testing of Public Employees}

If an employer cannot test its employees for drug use, the question of what process is due those employees who test positive is, of course, moot. However, a growing body of jurisprudence in state and lower federal courts indicates that under some conditions public employee drug testing can withstand constitutional scrutiny. This Part describes the circumstances under which a public agency can test its employees for drugs and the prospects for judicial approval of some prominent newly-proposed testing programs.

\section{A. The Fourth Amendment Jurisprudence of Public Employee Drug Testing}

From the earliest case dealing with drug testing of civilian public employees, ${ }^{21}$ all courts addressing the issue have recognized urinalysis tests as "searches" within the meaning of the fourth amendment. ${ }^{22}$ Therefore, in order for such tests to be permissible, they must be "reasonable."23 Courts have analyzed the reasonableness of such searches in several ways, balancing employee privacy interests against public safety, workplace safety, and efficiency interests.

10424 U.S. 319 (1976).

20470 U.S. 532 (1985).

${ }^{21}$ Division 241 Amalgamated Transit Union v. Suscy, 538 F.2d 1264, 1267 (7th Cir.), cert. denied, 429 U.S. 1029 (1976).

${ }_{22}$ See, e.g., McDonell v. Hunter, 809 F.2d 1302, 1307 (8th Cir. 1987) (listing cases finding urinalysis a search within the meaning of the fourth amendment); American Fed'n of Gov't Employees v. Weinberger, 651 F. Supp. 726, 732 (S.D. Ga. 1986) (same).

${ }^{23}$ U.S. ConsT. amend. IV. 
In general, courts have found drug testing to be constitutional when there is probable cause or "reasonable suspicion" of drug use. In Division 241 Amalgamated Transit Union v. Suscy, ${ }^{24}$ Chicago Transit Authority employees challenged as facially unconstitutional Authority rules allowing mandatory blood and urine testing, upon the recommendation of two supervisors, of employees involved in vehicle collisions or suspected of being under the influence of chemicals while on duty. ${ }^{25}$ The Seventh Circuit found the testing to be reasonable, balancing the public's interest in safety against the employees' expectations of privacy and held that "[u]nder these conditions and because 'a valid public interest justifies the intrusion contemplated,' probable cause exists." 28

When testing is performed absent probable cause or reasonable suspicion, many courts have found a constitutional violation. In cases involving police officers, ${ }^{27}$ fire fighters, ${ }^{28}$ and bus drivers and attendants, ${ }^{20}$ federal district courts have held drug testing unconstitutional because it was not done on the basis of a "reasonable suspicion, based on specific objective facts and the reasonable inferences from those facts in the light of experience," illegal drug use by specific employees. State courts have applied similar standards and have found fourth amendment violations in cases concerning the random urinalysis of firefighters and policemen, ${ }^{31}$ and school teachers. ${ }^{32}$ In addition, the Maryland Attorney General issued an opinion in 1986 stating that drug testing of a state employee was

24538 F.2d 1264 (7th Cir.), cert. denied, 429 U.S. 1029 (1976).

${ }^{25}$ See id. at 1267.

${ }^{28}$ Id. (quoting Camara v. Municipal Court, 387 U.S. 523, 539 (1967)).

${ }^{27}$ Feliciano v. City of Gleveland, 661 F. Supp. 578 (N.D. Ohio 1987) (police cadets); Bostic v. McClendon, 650 F. Supp. 245 (N.D. Ga. 1986) (police officer and court clerk); Penny v. Kennedy, 648 F. Supp. 815, 817 (E.D. Tenn. 1986) (police officers).

${ }^{28}$ Lovvorn v. City of Chattanooga, 647 F. Supp. 875, 882 (E.D. Tenn. 1986) (companion case to Penny, 648 F. Supp. 815); Capua v. City of Plainfield, 643 F. Supp. 1507, 1517 (D.N.J. 1986).

20 Amalgamated Transit Union, Local 1277 v. Sunline Transit Agency, No. CV 86-8270 RG(Gx) (C.D. Cal. July 7, 1987) (bus drivers and transit agency mechanics); Jones v. McKenzie, 628 F. Supp. 1500, 1508-09 (D.D.C. 1986) (drug testing of school bus attendant who was not a driver, without probable cause, was unreasonable).

${ }^{30}$ Bostic, 650 F. Supp. at 251.

s1 See, e.g., Gity of Palm Bay v. Bauman, 475 So. 2d 1322, 1325-26 (Fla. Dist. Ct. App. 1985) (actual testing of firefighters and proposed testing of police officers); Caruso v. Ward, 506 N.Y.S.2d 789, 791, 799 (Sup. Ct. 1986) (police officers in organized crime bureau); $c$. Turner v. Fraternal Order of Police, 500 A.2d 1005, 1008-09 (D.C. 1985) (testing of police officers in general is not a violation when regulation construed to require "a reasonable, objective basis").

${ }_{32}$ See Patchogue-Medford Congress of Teachers v. Board of Educ., 119 A.D.2d 35, 35, 505 N.Y.S.2d 888, 889 (App. Div. 1986), affd, No. 156 (N.Y. June 9, 1987) (WESTLAW, NY-CS database; LEXIS, NY library, NY file). 
valid only where there was a "reasonable, objective basis" for suspecting her of illegal drug use. ${ }^{33}$

More troublesome are cases in which courts have upheld drug testing absent reasonable suspicion. These courts have found a diminished expectation of privacy based, not on a specific suspicion that an employee is using drugs, but on the general nature of the employee's job. For example, in Shoemaker v. Handel ${ }^{34}$ the Third Circuit upheld the random testing of jockeys by the New Jersey Racing Commission. There was no reasonable suspicion or issue of public safety as in Division $241 .^{35}$ Instead, the court relied on the administrative search exception to the warrant requirement carved out by the Supreme Court for heavily regulated industries, and held that the heavy regulation of horse racing to maintain the appearance and reality of integrity diminished the jockeys' reasonable expectations of privacy and justified a random testing program. ${ }^{36}$

Shoemaker has been called "enigmatic" and has been "rejected or distinguished by all of the courts that have dealt with the mandatory drug testing of law enforcement personnel."37 However, it has been cited favorably by some courts. For example, in McDonell v. Hunterss the Eighth Circuit held that prison officials could test "uniformly or by systematic random selection" those employees who had regular contact with inmates in medium or maximum security prisons. ${ }^{39}$ The court allowed testing absent a warrant or reasonable suspicion based, not on the heavy regulation of the industry as in Shoemaker, but on an institutional interest in prison security. The court noted prison guards' diminished expectations of privacy because of the sensitive nature of their jobs, ${ }^{40}$ and stated its belief that blanket testing is an intrusion that "society will accept as reasonable."

s3 86 Op. Md. Att'y Gen. 055 (1986) (WESTLAW, MD-AG database).

s4 795 F.2d 1136 (3d Cir.), cert. denied, 107 S. Ct. 577 (1986).

so See supra notes $24-26$ and accompanying text.

s6 Shoemaker, 795 F.2d at 1142 (citing Donovan v. Dewey, 452 U.S. 594, 602-05 (1981) (warrantless inspection of coal mines); United States v. Biswell, 406 U.S. 311, 316-17 (1972) (gun selling); Colonnade Catering Corp. v. United States, 397 U.S. 72 , 76-77 (1970) (liquor industry)).

s7 American Fed'n of Gov't Employees v. Weinberger, 651 F. Supp. 726, 734 (S.D. Ga. 1986).

ss 809 F.2d 1302 (8th Cir. 1987).

39 Id. at 1308 (modifying district court's order enjoining urinalysis of correction employees except on reasonable suspicion and finding the uniform or random testing of prison employees constitutional); see also Rushton v. Nebraska Pub. Power Dist., 653 F. Supp. 1510, 1524-25 (D. Neb. 1987) (finding the administrative search exception applicable to the drug testing of persons working at a nuclear power plant).

10 See McDonell, 809 F.2d at 1306.

11 Id. at 1308. This language refers to Justice Harlan's concurrence in Katz v. United States, 389 U.S. 347, 361 (1967), establishing the test for determining what 
Similarly, when considering a Customs Service program of testing applicants for certain security-sensitive positions, one Fifth Circuit judge questioned the validity of the reasonable suspicion requirement for any law enforcement personnel. Concurring with the majority opinion, which denied a stay of an injunction against drug testing absent reasonable suspicion, Judge Higginbotham remarked that,

given the practice of testing and background checks required for so many government jobs, whether any expectations of privacy by these job applicants were objectively reasonable is dubious at best. Certainly, to ride with the cops one ought to expect inquiry, and by the surest means, into whether he is a robber. ${ }^{42}$

Judge Higginbotham was not on the panel when the Fifth Circuit decided the merits of the case, National Treasury Employees Union $v$. von Raab. ${ }^{43}$ Although the majority vacated the district court's injunction against the testing, it departed somewhat from Judge Higginbotham's reasoning. The court noted that the "power to take those steps necessary to carry on the business of government is not, of course, without limits. . . . [T]he government cannot, therefore, undertake searches of its employees simply by making consent a condition of employment." The von Raab court further stated that a purely administrative search was "not per se reasonable."45 But it held, after weighing the need for the test against its intrusiveness, that drug testing of employees seeking positions in drug law enforcement was reasonable even absent individualized suspicion. The court thus held that the nature of the job applied for diminished the employees' reasonable expectations of privacy. ${ }^{48}$ This conclusion was based partly on the position's being a sensitive one, ${ }^{47}$ and partly on its being analogous to a job in a heavily

privacy interests are protected by the fourth amendment. See McDonell, $809 \mathrm{~F} .2 \mathrm{~d}$ at 1306. See also Mack v. United States, 653 F. Supp. 70, 75 (S.D.N.Y. 1986) (FBI agent had diminished expectation of privacy that, coupled with the strong government interest in keeping agents drug-free, made testing without reasonable suspicion a reasonable search), affd on other grounds, 814 F.2d 120 (2d Cir. 1987).

${ }^{2}$ National Treasury Employees Union v. von Raab, 808 F.2d 1057, 1061 (5th Cir. 1987) (Higginbotham, J., specially concurring in denial of stay).

4s 816 F.2d 170 (5th Cir. 1987).

4 Id. at 178-179.

45 Id. at 179.

48 Id. at 180 ("Individuals seeking employment in drug interception know that inquiry may be made concerning their off-the-job use of drugs and that the tolerance usually extended for private activities does not extend to them if investigation discloses their use of drugs.").

47 See id. at 173. 
regulated industry. ${ }^{48}$ In this way, the von Raab decision encompassed the rationales of both $M c D o n e l l$ and Shoemaker.

One case seems to suggest that any employer may test its employees without probable cause or reasonable suspicion of drug use even if the employment is not in a heavily regulated industry or a sensitive position. In Allen $v$. City of Marietta, ${ }^{49}$ a district court implied that a public employer's interest in an efficient workplace always outweighs an employee's expectation of privacy. ${ }^{50}$ The reasoning in Allen conflicts with that in many drug testing cases, ${ }^{\text {s1 }}$ although the circuit court in

48 See id. at $179-80$.

40601 F. Supp. 482 (N.D. Ga. 1985).

so The court held that the employees-public utility workers-had no legitimate expectation of privacy on the job from urinalysis because

the government has the same right as any private employer to oversee its employees and investigate potential misconduct relevant to the employee's performance of his duties. Thus, a government employee's superiors might legitimately search her desk . . . for the proprietary purpose of preventing future damage to the agency's ability to discharge effectively its statutory responsibilities.

Id. at 491 . Therefore, the court concluded that the city "has a right to make warrantless searches of its employees for the purpose of determining whether they are using or abusing drugs which would affect their ability to perform safely their work with hazardous chemicals." Id. The case could have been decided under the reasonable suspicion standard, because the employees challenging the drug testing had been seen smoking marijuana on the job. See id. at 484.

81 See McDonell v. Hunter, 612 F. Supp. 1122, 1130 (D. Iowa 1985) ("There is no doubt about it-searches and seizures can yield a wealth of information useful to the searcher. (That is why King George III's men so frequently searched the colonists.) That potential, however, does not make a governmental employer's search of an employee a constitutionally reasonable one."), modified, 809 F.2d 1302 (8th Cir. 1987), quoted in Bostic v. McClendon, 650 F. Supp. 245, 250 n.2 (N.D. Ga. 1986), wited with approval in Capua v. City of Plainfield, 643 F. Supp. 1507, 1516 (D.N.J. 1986). Miller, Mandatory Urinalysis Testing and the Privacy Rights of Subject Employees: Toward a General Rule of Legality Under the Fourth Amendment, 48 U. PITT. L. REv. 201, 216-17 (1986), states the rule emerging from the cases following Division 241 as requiring that the "employee [be] in a position where the impairment of his or her faculties presents a clear and present danger to the physical safety of the employee, another employee, or a member of the public," and that there be reasonable suspicion that such employee is under the influence while in such position. This rule does not account for the Allen court's emphasis on the employer's right to search "for the proprietary purpose of preventing future damage to the agency's ability to discharge effectively its statutory responsibilities." Allen, 601 F. Supp. at 491 . Although the plaintiffs in Allen were in safety-sensitive positions, and there was a reasonable suspicion that they were smoking marijuana on duty, the court did not find these facts necessary to its decision. Rather, it implied that the city could search any employee who worked with hazardous materials.

Additionally, the Eighth Gircuit's decision in $\mathrm{McD}$ Donell, written subsequent to Miller's article, indicated that reasonable suspicion was not needed for urinalysis tests, assuming the tests were done uniformly or by systematic random selection, where workplace safety would be endangered by employee drug abuse. 809 F.2d at 1308. Thus, Miller's rule is more restrictive than some courts are willing to be. 
McDonell cited Allen favorably. ${ }^{52}$ In fact, the Allen court's reasoning has been rejected by the Supreme Court in O'Connor $v$. Ortega. ${ }^{53}$ In $O^{\prime}$ Connor, a case involving the search of an employee's desk and file cabinets, the Court noted that "[w]e have no occasion in this case to . . . address the proper Fourth Amendment analysis for drug and alcohol testing of employees." "st Nonetheless, eight members of the Court did "reject the contention . . . that public employees can never have a reasonable expectation of privacy in their place of work." "Bs

The Court found that the plaintiff in $O^{\prime}$ Connor did have a reasonable expectation of privacy in his desk and file cabinets, and five Justices found that he had such an expectation in his office as a whole. ${ }^{\text {b6 }}$ However, the Court reversed the court of appeals' summary judgment that the search in question was unreasonable. ${ }^{57}$ If an employee has a legitimate expectation of privacy in her workplace, it follows that she has at least an equal expectation of privacy in her bodily fluids. The plurality in $O^{\prime}$ Connor suggested that, when such an expectation exists, the proper standard for initiating a warrantless search is reasonable suspicion. ${ }^{88}$ The plurality also held that even when no warrant was required, "both the inception and the scope of the [search] must be reasonable."

However, the plurality noted that, "[g]iven the great variety of work environments in the public sector, the question of whether an employee has a reasonable expectation of privacy must be addressed on a case-by-case basis." ${ }^{\prime 60}$ This language indicates that the Court may be receptive to warrantless searches absent reasonable suspicion when the employees' expectations of privacy are diminished, as in Shoemaker and McDonell.

So far the three courts of appeals that have considered the constitutionality of public employee drug testing have upheld it despite the absence of reasonable suspicion in the three situations presented. Even

${ }^{52}$ See McDonell, 809 F.2d at 1308.

s3 107 S. Ct. 1492 (1987).

st Id. at 1504 n.*.

ss Id. at 1498; see also id. at 1508 (Blackmun, J., dissenting). Justice Scalia's concurring opinion generally supports the Allen approach, stating that searches that would be regarded as "reasonable and normal" in the private sector do not violate the fourth amendment. Id. at 1506 (Scalia, J., concurring).

${ }^{\circ 6}$ See id. at 1498-99; see also id. at 1505 (Scalia, J., concurring) (fourth amendment covered office), 1510 (Blackmun, J., dissenting) (same).

${ }^{57}$ Id. at 1504 .

s8 Id. at 1503 ("Ordinarily, a search of an employee's office by a supervisor will be 'justified at its inception' when there are reasonable grounds for suspecting that the search will turn up evidence that the employee is guilty of work-related misconduct.").

Io Id. (citing New Jersey v. T.L.O., 469 U.S. 325, 341 (1985)).

${ }^{60}$ Id. at 1498. 
if the Supreme Court eventually overrules drug testing in some or all of the situations presented in Shoemaker, McDonell, and von Raab, the existing case law makes it clear that a public employer may require an employee to submit to drug urinalysis when there is a reasonable suspicion of drug use, although it is uncertain just what constitutes "reasonable suspicion." drug testing, in some jurisdictions employees whose impairment would present a danger to public or workplace safety may be tested even absent objective grounds supporting a suspicion of drug use. ${ }^{62}$ It may be some time before a nationwide standard emerges for determining the constitutionality of drug testing. Meanwhile, we must look at the legality of current testing programs in light of the various existing judicial approaches to the issue.

\section{B. Fourth Amendment Analysis of Current Programs}

For several years, federal agencies concerned with transportation safety have been authorized to test employees for drug use. These regulations have generally required some reasonable basis to believe an employee is impaired on the job before she can be tested. ${ }^{63}$ Executive Order $12,564,{ }^{64}$ issued in September 1986, seeks to extend such testing to

61 See Bostic v. McClendon, 650 F. Supp. 245, 248 (N.D. Ga. 1986) (question of fact existed as to whether there was reasonable suspicion, where police chief had been informed by one officer that another officer had been seen smoking marijuana, the second officer was tested four months later, and the record was unclear whether the chief had received any information suggesting officer's drug use during intervening four months); King v. McMickens, 501 N.Y.S.2d 679, 680 (App. Div. 1986) ("reasonable suspicion" came from an informant who alleged petitioners were involved in illegal drug activities).

${ }_{62}$ See supra notes 34-52 and accompanying text. A district court has held that urinalysis is sufficiently more intrusive than the search at issue in $O^{\prime}$ Connor that the reasonable suspicion standard should apply even to police cadets. Feliciano v. City of Cleveland, 661 F. Supp. 578 (N.D. Ohio 1987); see also Amalgamated Transit Union, Local 1277 v. Sunline Transit Agency, No. CV 86-8270 RG(Gx) (C.D. Cal. July 7, 1987) (random testing of bus drivers and mechanics, absent reasonable suspicion, violates fourth amendment). But see Mullholland v. Department of the Army, $660 \mathrm{~F}$. Supp. 1565 (E.D. Va. 1987) (upholding testing of civilian employees maintaining helicopters to be used in evacuating national leaders in case of emergency); National Ass'n of Air Traffic Specialists v. Dole, 2 Indiv. Empl. Rts. Cas. (BNA) 68 (D. Alaska 1987) (using analysis similar to that of the plurality in $O^{\prime}$ Connor, random testing of air traffic controllers is reasonable under the fourth amendment).

os See, e.g., 14 C.F.R. § 91.11(d) (1987) (airline pilots may be required to submit drug test results when there is "reasonable basis to believe" they have used any drug that would affect the user's faculties contrary to safety); 49 C.F.R. $§ 219.301$ (c)(2)(i) (1986) (reasonable suspicion for urine test means the concurrence of two supervisory employees as to need for test).

of 3 C.F.R. 224 (1987). 
employees in all executive agencies in the federal government. ${ }^{65}$ Specifically, the order authorizes the head of each executive agency to test an employee for illegal drug use when "there is a reasonable suspicion that any employee uses illegal drugs," of an accident or unsafe work practice. ${ }^{67}$ This policy accords with even the most restrictive judicial rulings on drug testing. But the order also requires each agency head to establish a program for testing any employees in broadly defined "sensitive positions," with the agency head to determine the conditions and manner of testing. ${ }^{68}$

Executive Order 12,564 was intended to have, and probably will have, significance beyond the federal workforce. ${ }^{69}$ Therefore, the permissibility of testing programs developed by its authority will affect all drug testing of public employees. The order's most questionable provision, that dealing with employees in "sensitive positions," could be upheld under the rationales of Shoemaker and McDonell. With respect to any of the employees falling under this provision, the government could advance a public safety interest in avoiding impairment at least as great as the interest on which the racing commission relied in Shoemaker. ${ }^{70}$ And, as in McDonell and von Raab, it is quite possible that many courts would find a diminished expectation of privacy among these employees such that blanket or random testing would not be deemed an unreasonable search. ${ }^{71}$. In addition, this provision seems to be exactly

85 3 C.F.R. 224 (1987). The order applies to employees in any "employing unit or authority of the Federal government" except for the armed forces, Postal Service, Postal Rate Commission, and the judicial and legislative branches. Id.

${ }^{68} I d$. Read literally, this provision means that the agency can test any employee if there is reason to suspect that any employee uses illegal drugs; the suspicion need not be reasonable as to the specific employee being tested. The fact sheet issued with the order is clearer, stating that an employee can be tested "when there is a reasonable suspicion that the employee uses illegal drugs." See Executive Order Fact Sheet, 24 Gov't Empl. Rel. Rep. (BNA) 1299 (1986).

o7 Executive Order No. 12,564, 3 C.F.R. 224 (1987). An agency can also demand a test as a follow-up to counselling or rehabilitation as part of an Employee Assistance Program. Id. See infra text accompanying notes 192-95.

${ }_{68} I d$. A sensitive position is one in several prescribed categories, including any position filled by presidential appointment. It may also be any position "that the agency head determines involve[s] law enforcement, national security, the protection of life and property, public health or safety, or other functions requiring a high degree of trust and confidence." Id.

${ }^{69}$ The order's preamble states, "[t]he Federal government, as the largest employer in the Nation, can and should show the way towards achieving drug-free workplaces ...."Id. The Reagan administration's promotion of drug testing was influencing other government bodies even before Executive Order 12,564 was issued. See L.A. County to Consider Random Drug Testing, 24 Gov't Empl. Rel. Rep. (BNA) 1193 (1986) (county supervisors inspired by Reagan speech to subject themselves to drug testing as part of general program of screening county employees).

70 See supra notes 34-36 and accompanying text.

71 See supra notes 40, 46 and accompanying text. 
the type of drug testing which Judge Higginbotham would find reasonable. ${ }^{72}$

Assuming that all or part of the testing required by the order is consistent with the fourth amendment, the procedures it prescribes before and after testing become important. Thus far, only the Departments of Defense, Transportation, and Justice have announced programs to comply with Executive Order 12,564.73 The Defense and Transportation plans could probably withstand fourth amendment attack under the reasoning of Shoemaker and McDonell, since they allow for testing only when there is reasonable suspicion or when the employee's position has a direct effect on safety or security. ${ }^{74}$ However, a district court has enjoined a Defense Department program of testing civilian employees devised prior to the release of Executive Order 12,564. The court in American Federation of Government Employees $v$. Weinberger ${ }^{25}$ ruled that it would permit testing of civilian police officers on the base in question only where there was reasonable suspicion or "where accidents involving government property have occurred." "76 The opinions in $O^{\prime}$ Connor leave open both the possibility that no warrantless drug testing will be allowed without reasonable suspicion, and the possibility that the Supreme Court may adopt an analysis of drug testing similar to that in McDonell. ${ }^{77}$

Even if the courts were to abandon the approaches of Shoemaker, McDonell, and von Raab somewhat, there is another theory under which blanket or random drug testing could be found constitutional. In the context of an "administrative search," the Supreme Court has held that the general need to inspect buildings for fire and health hazards can be weighed in determining whether there is probable cause to issue a warrant for an individual building. ${ }^{78}$ The Court also has stated that,

72 See supra note 42 and accompanying text.

7s See 52 Fed. Reg. 1340 (1987) (to be codified at 32 C.F.R. $§ 60(a)$ ) (Defense Department's proposed rules essentially tracking the language of Executive Order 12,564); Dole Order Says 26,500 DOT Workers Will Be Subject to Random Checks, 25 Gov't Empl. Rel. Rep. (BNA) 88 (Jan. 26, 1987) (Department of Transportation order requiring testing on demand for air traffic controllers and other employees whose jobs have direct impact on public health and safety, protection of life and property, or national security; all employees to be tested as part of annual physical, or if under reasonable suspicion, or as part of accident investigation); 52 Fed. Reg. 2118-21 (1987) 2118 (to be codified at 49 C.F.R. $\S 219$ ) (announcement of Transportation Department's informal safety inquiry into alcohol and drug use in railroad operations); Quick Challenge Likely to Drug-Testing at Justice, Nat'l L.J., Feb. 23, 1987, at 5, col. 1.

74 See supra text accompanying note 62.

7s 651 F. Supp. 726 (S.D. Ga. 1986).

78 Id. at 739.

77 See supra notes 38-41 and accompanying text.

78 See Camara v. Municipal Court, 387 U.S. 523, 535-37 (1967). 
though a warrantless search for violations of occupational safety rules is unconstitutional, entitlement to a warrant does not depend on probable cause to believe that a violation exists on a particular site. ${ }^{79}$ Based on such reasoning, a government agency might obtain a warrant to test individual employees by showing a need to detect drug use in order to enforce workplace safety regulations. ${ }^{80}$ Such testing would differ from that allowed in Shoemaker, McDonnell, and von Raab mainly in that it would require that a judge rule on the need for it before rather than after the fact. ${ }^{81}$

Though many courts may not go as far as the Allen court did and hold that an agency's ability to discharge its statutory duty always outweighs an employees privacy interest, ${ }^{\mathbf{B 2}}$ they might agree that the general danger posed by drugs in some workplaces is sufficient probable cause to warrant a search of each employee. It should be noted, however, that random or blanket testing allowed by such warrants would require guidelines limiting the discretion of the people conducting the tests, especially with regard to the selection of employees to be tested. ${ }^{83}$

78 Marshall v. Barlow's, Inc., 436 U.S. 307, 320-21 (1978) (investigation of Occupational Safety and Health Act violations).

${ }_{80}$ That showing of a need to detect drug use might require evidence of a drug problem at the particular workplace rather than a showing of a drug problem in society in general. See McDonell, 809 F.2d at 1311 (Lay, C.J., concurring in part and dissenting in part) ("Neither the environment of the prison workplace nor a well-meant desire to stem the use of illicit drugs should be used to tip the balance of Fourth Amendment interests in favor of the state without factual findings on the record to prove the institution's real needs.").

${ }^{81}$ The Camara Court cited three factors supporting the reasonableness of the area search in question in that case. One of these factors, that the searches were "neither personal in nature nor aimed at the discovery of evidence of crime," Camara, 387 U.S. at 537, does not apply to drug urinalysis testing. Another factor was the "long history of judicial and public acceptance" of area house safety inspections. Id. While drug testing may not have such a history, neither does it have a long history of public disapproval. It is simply a phenomenon that has not existed long enough for there to be a "historical" public attitude toward it. Finally, the Camara Court noted that "the public demands that all dangerous conditions be prevented or abated, yet it is doubtful that any other canvassing technique would achieve acceptable results." Id. This factor seems directly applicable to urinalysis for drug use.

The reasoning of Camara could support a general warrant for drug testing if the issuing judge accepts, as the von Raab court did, that urinalysis is less intrusive than an invasion of the home. von Raab, 816 F.2d 170, 177 (5th Cir. 1987). A court could still grant this kind of warrant in some situations while remaining more skeptical of the reasonableness of drug urinalysis than were the Shoemaker, McDonell, and von Raab courts.

${ }^{82}$ Allen, 601 F. Supp. at 491.

89 Cf. Delaware v. Prouse, 440 U.S. 648,663 (1979) (random spot checks to detect invalid vehicle registrations violate the fourth amendment). There is language in Justice White's opinion in Prouse that supports blanket searches. "This holding does not preclude the State of Delaware . . . from developing methods for spot checks that involve less intrusion or that do not involve the unconstrained exercise of discretion. Questioning all oncoming traffic at roadblock-type stops is one possible alternative." Id. 
Provided that such safeguards are present, an administrative search warrant is one more means by which public employers can evade fourth amendment objections to testing of their employees for drug use.

Whether an employer tests only on reasonable suspicion, on an employee's reduced expection of privacy, or on an administrative search warrant, it should be apparent that constitutional challenges to drug testing itself are likely to be unsuccessful in many employment contexts. Therefore, many public employees will continue to be subject to mandatory drug testing. The next Part discusses how due process considerations come into play when such employees are tested.

\section{Due Process Rights of the Public Employee}

The fifth and fourteenth amendments provide that no person shall be deprived of "life, liberty, or property" without due process of law. ${ }^{\mathbf{8 4}}$ The Supreme Court has arrived at an understanding of how one acquires a "property" right in one's status vis-à-vis the government-that is, one's position in a legal relationship to the government. The Court is less clear, however, on what government actions, other than actual confinement, infringe protected liberty interests. This Part sets out the property and liberty interests that are at stake when a public agency takes action against its employees on the basis of a drug test. It then describes the analysis the Supreme Court has prescribed for determining what procedures the due process clauses require in a given situation.

\section{A. Employment as "Property"}

Until the 1950's, courts recognized a distinction between "rights" stemming from the text of the Constitution or the common law, and "privileges" granted by the government. ${ }^{85}$ The latter, including positions in government service, could be removed without recourse on the part of the holder. ${ }^{86}$

See also Shoemaker, 795 F.2d at 1143 (fact that scheme of tests leaves administrator with no discretion one of factors in reasonableness of search). It has been suggested that a proper standard for allowing warrantless drug testing is that of "business emergency." An employer would be allowed to test if an employee objectively appeared to be under the influence and the nature of the employee's work made it likely that chemical impairment would cause. injury. See Note, Urinalysis and the Public Employer-Another Well-Delineated Exception to the Warrant Requirement?, 39 OKLA.

L. REv. 257, 272-73 (1986).

8. U.S. ConST. amends. V, XIV, $\S 1$.

ss See L. Tribe, American Constrtutional Law 509-10 (1978).

so See McAuliffe v. Mayor of New Bedford, 155 Mass. 216, 220, 29 N.E. 517, 517-18 (1892) (where policeman challenged firing on first amendment grounds, he 
The end of the right-privilege distinction was gradual, but it was effectively complete by $1967 .^{87}$ This change in the Court's view of the government's relations with individuals was of course necessary for the development of today's due process protection of employment rights. But it was not sufficient without some legal doctrine by means of which employees could enforce their rights in court. ${ }^{88}$ The appearance of the "entitlement" theory-the idea that the holder of a governmentally bestowed benefit has rights in that benefit analogous to traditional rights in real and personal property - was also a needed step. The entitlement theory emerged with Charles Reich's article, The New Property, in $1964,^{89}$ and the Supreme Court applied it in Goldberg $v$. Kelly ${ }^{90}$ in 1970 , where it held that a welfare recipient was entitled to an evidentiary hearing before his benefits were terminated.

It soon developed that where state positive law created an expectation of tenure in one's public job, the constitutional guarantee of due process governed the manner in which this tenure could be removed. ${ }^{91}$ Until recently it was unclear whether that guarantee had any content outside the procedural provisions of the positive law that created the entitlement in the first place. Justice Rehnquist, writing for a plurality of three in Arnett $v$. Kennedy, ${ }^{92}$ stated that the law establishing a property right also established the process that was due on its removal.

Wayne Kennedy, the plaintiff in Arnett, was fired on the authority of a federal statute providing that civil service employees could only be dismissed for cause, but were not entitled to a hearing until after they were discharged. The plurality held that Kennedy had a limited property right in his job that "was itself conditioned by the procedural limitations which had accompanied the grant of that interest." $" 98$ On the

\footnotetext{
"may have a constitutional right to talk politics but he has no constitutional right to be a policeman"). See also Bailey v. Richardson, 182 F.2d 46, 57-58, 65 (D.C. Cir. 1950), affd by an equally divided Court, 341 U.S. 918 (1951) (fifth amendment does not restrict President's right to remove any government employee suspected of disloyalty without any explanatory notice).

${ }^{87}$ See generally Van Alstyne, The Demise of the Right-Privilege Distinction in Constitutional Law, 81 HaRv. L. REv. 1439 (1968) (reviewing and evaluating the means by which the Supreme Court has avoided the consequences of the right-privilege distinction).

${ }^{83}$ See Van Alstyne, Cracks in "The New Property": Adjudicative Due Process in the Administrative State, 62 CoRnell L. Rev. 445, 446-49 (1977) (describing demise of right-privilege distinction and noting that it did not afford person whose benefit was removed the means to discover whether it was removed unconstitutionally or not).

8973 YALE L.J. 733 (1964).

90 397 U.S. 254, 266-71 (1970).

91 See Board of Regents v. Roth, 408 U.S. 564, 577-79 (1972); Perry v. Sindermann, 408 U.S. 593, 599-601 (1972).

${ }^{22} 416$ U.S. 134 (1974).

es Id. at 155. Justice Rehnquist's opinion stated that "where the grant of a sub-
} 
other hand, six Justices maintained that once the government created the property interest, procedural rights attached that were independent of the law creating the interest. ${ }^{94}$

The Court appears to have settled the issue in Cleveland Board of Education v. Loudermill. ${ }^{\text {ss }}$ Writing for eight Justices, Justice White concluded:

'Property' cannot be defined by the procedures provided for its deprivation any more than can life or liberty. The right to due process is conferred, not by legislative grace, but by constitutional guarantee. While the legislature may elect not to confer a property interest in [public] employment, it may not constitutionally authorize the deprivation of such an interest, once conferred, without appropriate procedural safeguards. ${ }^{98}$

The Court held that two school district employees had been denied due process because they were fired, under an Ohio civil service statute, without a pretermination opportunity to respond to the charges against them. ${ }^{87}$

\section{B. The Public Employee's Liberty Interest}

While it is fairly settled as to how a property right in a public job can be created, ${ }^{98}$ an employee's job status is not the only interest at

stantive right is inextricably intertwined with the limitations on the procedures which are to be employed in determining that right, [an employee] . . . must take the bitter with the sweet." Id. at 153-54. This position received some support in Bishop v. Wood, 426 U.S. 341, 343-47 (1976) (no property right exists where state law first requires some guarantee of permanence, and statute creating interest merely prescribes procedures to be followed in effecting discharge).

of Justice Powell and Blackmun concurred in part and concurred in the result in part, 416 U.S. at 167, but did not join the "bitter with the sweet" part of the majority opinion, see supra note 93; Justice White concurred with part of the majority opinion and dissented in part, 416 U.S. at 188; Justice Marshall wrote a dissenting opinion joined by Justices Douglas and Brennan, id. at 211.

gs 470 U.S. 532 (1985).

Id. at 541 (quoting Arnett, 416 U.S. at 167 (Powell, J., concurring in part and concurring in result in part)).

${ }^{97}$ Id. at 547. The fact that Loudermill involved a state rather than a federal statute helps somewhat to explain the difference in result between this case and Arnett. Justices Powell and Blackmun probably gave greater weight to the judgment of Congress than to that of the Ohio legislature in determining whether the process available under the statute was all that was "due." See Arnett, 416 U.S. at 169 n.4 (noting federal government's general policy of not giving pretermination evidentiary hearings, emphasizing federal government's efficiency interest).

os See Board of Regents v. Roth, 408 U.S. 564, 577 (1972) (property interest must be grounded in some form of positive law); Perry v. Sindermann, 408 U.S. 593, 601 (1972) (property interest in a job can arise from "mutually explicit understandings" 
stake when discipline or discharge is based on a drug test. The Supreme Court has recognized that marking a citizen with a "badge of infamy" infringes her liberty and thus implicates the due process clause. ${ }^{99}$ In fact, the Loudermill opinion mentioned the restrictive effect a wrongful discharge can have on an employee: "While a fired worker may find employment elsewhere, doing so will take some time and is likely to be burdened by the questionable circumstances under which he left his previous job."100

The Supreme Court in Paul v. Davis ${ }^{101}$ held that publishing a citizen's name on a list of "known shoplifters" did not deprive him of his liberty because applicable state law did not "vouchsafe" any right to enjoyment of one's reputation. Since the plaintiff's legal status did not change, his liberty was not taken away. ${ }^{102}$ But such considerations appear not to have guided the Loudermill Court. The Court noted that there was no deprivation-of-liberty claim since no adverse information about Loudermill had been published. It did not question whether Loudermill had a liberty interest at all in his reputation. ${ }^{103}$

The Court simply could have been trying to avoid addressing an issue it did not have to decide, since Loudermill obtained relief on other grounds. Alternatively, the Court, by not applying Paul when it could have, may have demonstrated doubts about that case's general validity. The latter interpretation is consistent with Professor Tribe's criticism

between employer and employee); see also McLaurin v. Fischer, 768 F.2d 98, 102 (6th Cir. 1985) (doctor had property right in directorship of department if he had "explicit understanding" with state that position would be permanent or if "common law" practice existed whereby directorships were treated as permanent). In general, an employee who can only be fired "for cause" has a property interest, see, e.g., Gurish v. McFaul, 801 F.2d 225, 226 (6th Cir. 1986); Jungels v. Pierce, 638 F. Supp. 317, 320 (N.D. Ill. 1986). Some public employees are "at will," and have no property rights to their jobs. See, e.g., Mack v. United States, 653 F. Supp. 70, 73 (S.D.N.Y. 1986) (FBI agent), affd, 814 F.2d 120 (2d Cir. 1987); McDonald v. Krajewski, 649 F. Supp. 370, 378 (N.D. Ind. 1986) (court employee serving "at the pleasure of" judge).

${ }^{2}$ See Wisconsin v. Constantineau, 400 U.S. 433, 437 (1971) (posting person's name as one to whom liquor may not be sold because of drinking problem is deprivation requiring due process); Jenkins v. McKeithen, 395 U.S. 411, 427-28 (1969) (when labor-management inquiry board makes finding of guilt of crime, due process implicated); Wieman v. Updegraff, 344 U.S. 183, 190-91 (1952) (state cannot bar one-time members of subversive groups from state employment without distinguishing innocent association from knowing association).

100 Loudermill, 470 U.S. at 543.

101424 U.S. 693 (1976).

102 Id. at 712.

${ }^{108}$ Loudermill, 470 U.S. at 547 n.13 (Loudermill did not suffer loss of liberty through accusation hanging over his head for nine months before hearing, as there was no evidence that the reason for his firing-dishonesty in filling out his job application-was published). See Jones v. McKenzie, 628 F. Supp. 1500, 1505 (D.D.C. 1986) (even though employer did not make finding of drug use public, such finding remained available for automatic publication to any prospective future employer). 
of $\mathrm{Paul}$ as departing significantly from precedent concerning the liberty interest in one's reputation. ${ }^{104}$

The District of Columbia Circuit has indicated that Paul does not preclude a deprivation of liberty claim by a discharged employee. The plaintiff in Doe v. Department of Justice ${ }^{\mathbf{1 0 5}}$ was discharged for alleged unprofessional and dishonest conduct. The court stated that she did state a claim of deprivation of liberty because the charges stigmatized her and effectively precluded her from future government employment. ${ }^{108}$

Damaging an employee's reputation is not the only way a termination decision can deprive her of liberty. The concept of self-determination, a vital part of political liberty, is a reflection of the moral value of individual dignity. ${ }^{107}$ If the state denies a person any means of influencing decisions that affect her, it denigrates the value of that person as an individual. Therefore, freedom from arbitrary administrative decisions, or the right to procedural protections, safeguards personal dignity and can be seen as a substantive liberty right. ${ }^{108}$

There may be another constitutionally-protected interest in one's job. Depriving someone of her job impairs her ability to enjoy life, thus, arguably, implicating the "life" interest that goes hand in hand with "liberty" and "property" in the due process clauses. ${ }^{100}$ Like the substantive right to freedom from arbitrary administrative decisionmaking, this "life interest" in employment has not received judicial recognition. However, constitutional analysis has often changed as new social institutions, not contemplated by earlier interpretation, have appeared. ${ }^{\mathbf{1 1 0}}$

104 See L. TRIBE, supra note 85, at 527-29; see also Monaghan, Of "Liberty" and "Property," 62 CoRnell L. REv. 405, 426-27 (1977) (Paul cuts against our political and constitutional tradition).

105753 F.2d 1092 (D.C. Cir. 1985).

108 See id. at 1104-05.

${ }^{107}$ See L. TRIBE, supra note 85, at 560; Mashaw, The Supreme Court's Due Process Calculus for Administrative Adjudication in Mathews v. Eldridge: Three Factors in Search of a Theory of Value, 44 U. CHI. L. REv. 28, 49-50 (1976).

108 See Mashaw, supra note 107, at 50.

109 See Brief for Cross-Petitioner at 23-24, Loudermill, 470 U.S. 532 (1985) (No. 83-6392) (tracing history of concept of liberty from Magna Carta to U.S. Constitution, concluding that "when Madison wrote the word 'life' in the Bill of Rights, it seems clear . . . that it was understood . . to mean 'the enjoyment of life,' and that government was not to interfere with, impair or deprive a free citizen of his enjoyment of life without due process of law").

${ }_{110}$ See Brown v. Board of Education, 347 U.S. 483, 489-93 (1954) (application of equal protection clause to public education must consider the present widespread nature of public schooling, not the limited social role it played at the time of the enactment of the fourteenth amendment); see also Rabin, Job Security and Due Process: Monitoring Administrative Discretion Through a Reasons Requirement, 44 U. CHI. L. REv. 60, 60-62 (1976) (accelerated growth of the public sector and "proliferation of relationships binding the citizen to the state" from the mid-1950's led to the recognition of the enti- 
The widespread testing of employees' bodily fluids is a phenomenon unprecedented in our history, as was the wide distribution of government benefits Reich described in The New Property. ${ }^{111}$ Accordingly, it would be appropriate for the courts to expand the range of interests they consider, when determining both whether a deprivation has occurred and what process is due before the government can legally carry out such a deprivation.

\section{G. Determining What Process is Due: Mathews v. Eldridge and its Offspring}

According to the Supreme Court, the elements of procedural due process are notice and the opportunity to be heard. ${ }^{112}$ The right to respond to the charges against one arises before the protected interest is terminated. As the Court made clear in Loudermill, "[ $t]$ he tenured public employee is entitled to oral or written notice of the charges against him, an explanation of the employer's evidence, and an opportunity to present his side of the story." tected interest does not determine what constitutes sufficient opportunity to present the employee's case. ${ }^{114}$

The required pretermination procedure need not be a full evidentiary hearing in all cases. In determining whether the Constitution requires a given procedure, the Supreme Court in each situation will apply the balancing test articulated in Mathews $v$. Eldridge. ${ }^{115}$ The analysis considers three interests:

First, the private interest that will be affected by the official action; second, the risk of erroneous deprivation of such interest through the procedures used, and the probable value, if any, of additional or substitute procedural safeguards; and finally, the Government's interest, including the function involved and the fiscal and administrative burdens that the additional or substitute procedural requirement would entail. ${ }^{116}$

tlement theory in Goldberg and the cases that followed it).

111 See Reich, supra note 89, at 734-39 (describing "government largesse" as a new form of wealth).

112 See Mullane v. Central Hanover Bank \& Trust Co., 339 U.S. 306, 313 (1950).

${ }_{113}$ Loudermill, 470 U.S. at 546.

114 Id. at 541 ("[O]nce it is determined that the Due Process Clause applies, the 'question remains what process is due.' The answer to that question is not to be found in the Ohio statute." (citation omitted)).

115424 U.S. 319 (1976).

116 Id. at 335. 
Mathews and subsequent Supreme Court decisions show a tendency to favor the government interest when it is at all substantial, and to find relatively minimal pretermination procedures constitutionally adequate. For example, in Schall v. Martin, ${ }^{117}$ a juvenile defendant was held in preventive detention pending trial and was denied a hearing to determine whether there was probable cause to hold him. The state's asserted interest in preventing pretrial crime was held to overcome the suspect's liberty interest in avoiding detention, so that denial of the probable-cause hearing did not violate due process. ${ }^{118}$ In Schweiker $v$. McClure, ${ }^{119}$ where the government only asserted an interest in cost and convenience, the Court emphasized the low risk of error as the decisive factor in its decision not to find a denial of due process. ${ }^{120}$ The next Part argues that in the context of mandatory drug testing, the individual interests involved combined with the risk of error must be the focus of the inquiry into what process is due.

\section{What Process Is Due When Public Employers Test for DRUGS}

This Part first looks at the governmental interest in speedy removal of unsatisfactory employees-in this context, those who impair safety, efficiency, or security by using illegal drugs. While the general goal of "achieving a drug-free [public] workplace"121 does require the dismissal of employees who are unable or unwilling to stop using drugs, this goal can still be met regardless of some administrative delay in the final dismissal of such workers. ${ }^{122}$ On the other hand, there is a

\footnotetext{
117467 U.S. 253 (1984).

118 Id. at 263.

110456 U.S. 188 (1982).
}

${ }^{120} I d$. at 198-200. When the Court has found the state-provided procedure to be inadequate, it has usually found the state interest branch of the Mathews test to be especially weak. Compare Lassiter v. Department of Social Services, 452 U.S. 18, 3133 (1981) (emphasizing low risk of error-small likelihood of different result had counsel been appointed-in parental rights case) and United States v. Raddatz, 447 U.S. 667, 677-81 (1980) (low risk of error when magistrate rules on supression of evidence) and Board of Curators of University of Missouri v. Horowitz, 435 U.S. 78, 86 n.3 (1978) (emphasizing Board's interest and low risk of error) with Santosky v. Kramer, 455 U.S. 745, 758-68 (1982) (parental interest in retaining custody and risk of error outweigh state's fiscal and administrative convenience interests in having low standard of proof in parental rights termination cases) and Logan v. Zimmerman Brush Co., 455 U.S. 422, 435 (1982) (state agency's "insubstantial" interest in avoiding hearing stale claims does not override claimant's right to hearing on merits, where agency was responsible for failure to hear claim within limitation period) and Memphis Light, Gas \& Water Div. v. Craft, 436 U.S. 1, 18 (1978) (utility company required to give pretermination opportunity to challenge billing error).

121 Exec. Order No. 12,564, 3 C.F.R. 224 (1987).

122 See Cleveland Bd. of Educ. v. Loudermill, 470 U.S. at 544 (the government 
strong public interest in quickly removing people from positions where their impairment can cause immediate public harm.

The Grateful Dead's vision of Casey Jones "Driving that train/ High on cocaine"123 has become all too true. ${ }^{124}$ But employee drug abuse poses dangers other than intoxicated railroad engineers. Recent revelations of government personnel selling national security information purely for profit ${ }^{\mathbf{1 2 5}}$ raise the possibility of employees resorting to espionage or theft to support expensive drug habits. Safety, efficiency, and security concerns constitute the governmental-interest side of the Mathews test. The rest of this section will discuss the risk of error inherent in currently available drug testing methods, and the procedures that will be necessary in order to protect the strong individual interests jeopardized by these tests.

\section{A. Risk of Error}

Several methods of testing urine for the presence of drug metabolites $^{128}$ are in widespread use. Not surprisingly, the cheapest and easiest of these tests to administer, and thus the most often used, are the least reliable. However, even the most sophisticated methods cannot guarantee 100 percent accuracy, and even when a positive test result is accurate, it is not always clear what that means. ${ }^{127}$

\section{Testing Methods}

The easiest and cheapest urinalysis methods are immunoassays, the most widespread being the Enzyme-Multiplied Immunoassay Technique ("EMIT") designed by the Syva Corporation, ${ }^{128}$ and the other being Radioimmunoassay ("RIA") performed with kits available from several manufacturers. These tests measure the presence of a specific chemical substance. A portion of the urine specimen is added to a

also has an interest in keeping qualified people at work and off the welfare rolls).

${ }_{123}$ R. Hunter, Casey Jones ( $\odot$ Warner Brothers, Inc. 1970).

124 See, e.g., Drug Test Failed by 3 at SEPTA after Dec. Crash, Phila. Inq., Jan. 17,1987 , at $A 1$, col. 1 (engineer of one train in commuter rail collision tested positive for cocaine).

${ }_{125}$ See Spy Ring-The Untold Story of the Walker Case, N.Y. Times, June 29, 1986, § 6 (Magazine), at 14. (FBI convinced that espionage operation lasting nearly 20 years motivated only by money).

${ }^{128}$ A metabolite is an organic compound produced by the processes involved in the maintenance of life. AmERICAN HeRITAge DictionaRY OF THE ENGlish LANGUAGE 824 (1979).

127 See infra notes $155-63$ and accompanying text.

$1282 \mathrm{M}$. Houts, R. Baselt \& R. Graven, Courtroom Toxicology $\S \S 30.01-30.06$ (1986) [hereinafter Courtroom ToxicoloGY]. 
solution containing an antibody ${ }^{129}$ and a known drug. If the drug being sought is present in the urine, it displaces the known drug and binds itself to the antibody. The amount of the displaced drug is then measured, yielding the amount of the sought drug in the urine. ${ }^{\mathbf{1 3 0}}$

Thin-layer chromatography ("TLC") and gas chromatography ("GC") separate different compounds within the specimen, and identify them by various characteristics such as the rate at which they react with another compound. ${ }^{131}$ These methods require more expensive equipment and more time than do the immunoassays, and must be done under laboratory conditions. ${ }^{132}$ Mass spectrometry ("MS") is a highly sophisticated identification technique that yields a permanent graphic representation of a compound's characteristics. ${ }^{133} \mathrm{MS}$ is often used in combination with gas chromatography, forming the GC/MS method. ${ }^{134}$

\section{Reliability of These Methods}

Immunoassay tests carry a strong risk of "false positives," or erroneous indications that a particular drug is present in the urine. Part of this risk is attributable to cross-reactivity, or the inability to distinguish between the drug being measured and other drugs that can cause similar reactions with the test compound. ${ }^{135}$ EMIT has been found to be ninety-five percent accurate or better in laboratory studies, ${ }^{136}$ and RIA

129 An antibody is a protective material found naturally in the body, or created by the body's immunological system in response to the introduction of specific foreign materials. Id. at $\S 30.01[2]$.

130 See id. at $\$ \S 30.03[5], 30.04$.

131 See id. at $\$ \S 21.01-21.08,22.03$.

132 See id. at $\$ \$ 21.10$ (much of ultimate value of TLC test depends on personal skills of technician), 22.09[4] (good quality control and complete understanding of the analytical procedures must be present for successful GC). RIA must also be performed in a licensed laboratory because it uses radioactive materials. Id. at $\S 30.08$. However, unlike TLC and GC, RIA can be taught to inexperienced technicians. Id. at $\S 30.07$ See also Comment, Admissibility of Biochemical Urinalysis Testing Results for the Purpose of Detecting Marijuana Use, 20 WAKE FoREst L. Rev. 391, 394-95, 397-98 (1984) (discussing gas chromatography tests and problems associated with various laboratory procedures).

iss See Courtroom Toxicology, supra note 128, at $\$ \$ 23.01-23.05$.

134 See R.L. Foltz, A. Fentiman \& R.B. Foltz, GC/MS Assays for Abused Drugs IN BoDy FuUids 1-2 (National Institute on Drug Abuse Research Monograph No. 32, 1980) [hereinafter GC/MS Assays].

135 Courtroom Toxicology, supra note 128 , at $\S 30.09$.

1s6 See Peranzo v. Goughlin, 608 F. Supp. 1504, 1511 (S.D.N.Y. 1985) (citing laboratory studies); Abercrombie \& Jewell, Evaluation of EMIT and RIA High Volume Test Procedures For THC Metabolites in Urine Utilizing GC/MS Confirmation, $10 \mathrm{~J}$. ANalytical Toxicology 178, 179 [hereinafter Evaluation] (97.3\% of samples tested positive by both EMIT and RIA confirmed by GC/MS); Kogan, Al Razi, Pierson \& Willson, Confirmation of Syva Enzyme Multiple Immunoassay Technique (EMIT) d.a.u. and Roche Abuscreen Radioimmunoassay (RIA) Urine Cannabinoid 
has produced similar results. ${ }^{137}$ However, reported experiments do not necessarily reflect the conditions under which large-scale employee testing is done. Sloppy laboratory practices, such as failure to clean equipment and specimen containers properly, are more likely as the laboratory's volume of work increases. A blind study of drug screening labs by the Centers for Disease Control in 1981 revealed false-positive rates of up to sixty-six percent for some drugs. ${ }^{138}$ In addition, the Army conceded that 69,000 positive results reported for soldiers in 1982 and 1983 were scientifically "unsupportable." ${ }^{139}$ Clearly, reported accuracy rates do not justify blind faith in screening techniques such as EMIT and RIA.

Some courts have held that EMIT is reliable enough for a single positive result to justify disciplining prison inmates. ${ }^{140}$ Others have found a positive EMIT result confirmed by a second EMIT test to be sufficiently accurate to satisfy due process in inmate discipline cases. ${ }^{141}$ If the court finds as a matter of fact that EMIT is ninety-five percent accurate, that test meets the beyond-a-reasonable-doubt standard of proof, which is often the standard in drug discipline cases. ${ }^{142}$ Some

Immunnassays by Gas Chromatographic/Mass Spectrometric (GC/MS) and BondeaPhase Adsorption/Thin-Layer Chromatographic (BPA-TLC) Methods, 31 J. FORENsIC SCI. 494, 497-98 (1986) [hereinafter Confirmation] (all of samples shown by EMIT to have some trace of THC confirmed by GC/MS and TLG, and none of samples known to be absent THC tested positive by EMIT); Sutheimer, Yarborough, Hepler \& Sunshine, Detection and Confirmation of Urinary Cannabinoids, $9 \mathrm{~J}$. ANALYTICAL TOXICOLOGY 156, 158-59 (1985) [hereinafter Detection] (231 of 242 positive EMIT results-95.4\% - confirmed by TLC).

${ }^{137}$ See Evaluation, supra note 136, at 179.

${ }^{198}$ See Hansen, Caudill \& Boone, Crisis in Drug Testing. Results of CDC Blind Study, 253 J. A.M.A. 2382, 2386 (1985). Most of the labs studied displayed even higher rates of false negative results, id., indicating that the testing done by those labs was not accomplishing its purpose of identifying individuals who used drugs.

139 Diamond, Army Veterans May Appeal Drug Test Punishments, 19 Clearinghouse Rev. 145, 145 (1985).

${ }^{140}$ See Spence v. Farrier, 807 F.2d 753, 756 (8th Cir. 1986); Harmon v. Auger, 768 F.2d 270, 276-77 (8th Cir. 1985); Jensen v. Lick, 589 F. Supp. 35, 38-39 (D.N.D. 1984).

${ }^{141}$ See Wykoff v. Resig, 613 F. Supp. 1504, 1512 (N.D. Ind. 1985) (EMIT result was confirmed by TLC, but court stated that second EMIT test "or its equivalent" was sufficient); Peranzo v. Coughlin, 608 F. Supp. 1504 (S.D.N.Y. 1985); Crowell v. Wilkenson, Civ. A. 82-1283 (W.D. Pa. Oct. 12, 1983) (on WESTLAW, DCT database), affd, 738 F.2d 421 (1984).

${ }^{142}$ See Peranzo, 608 F. Supp. at 1512 ("[T]he probabilities associated with the various standards of proof may be fairly estimated as $50+\%$ for preponderance of the evidence, $70 \%$ for clear and convincing evidence, above $80 \%$ for clear, unequivocal and convincing evidence, and $95+\%$ for evidence beyond a reasonable doubt."), citing United States v. Fatico, 458 F. Supp. 388, 403-06 (E.D.N.Y. 1978) (Weinstein, J.), affd, 603 F.2d 1053 (2d Cir. 1979), cert. denied, 444 U.S. 1073 (1980); T.

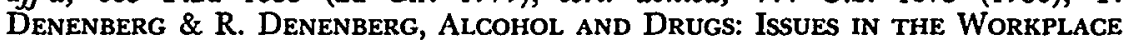
54-57 (1983) (beyond a reasonable doubt is often the standard in drug discipline cases). 
courts, however, are not so trusting of EMIT's accuracy. ${ }^{143}$ The consequences of falsely labelling a public employee as an illegal drug user ${ }^{\mathbf{1 4 4}}$ require the highest standard of proof in any personnel action based on urinalysis results.

In such proceedings, positive results of EMIT or RIA tests should be confirmed by another, more sophisticated, test in order to reduce the risk of error to an acceptable level. ${ }^{145}$ Even the manufacturer of EMIT recommends confirmation by a separate technique if high accuracy is desired, specifically mentioning GG. ${ }^{146}$ TLC is well regarded, also, as a confirmation technique, ${ }^{147}$ though it has disadvantages that militate against its complete reliability. ${ }^{\mathbf{1 4 8}}$

The GG/MS combination is the best method for confirming positive results. Although each GC/MS test costs considerably more than an EMIT screening test, ${ }^{148}$ the technique is more accurate than any other ${ }^{150}$ and has the advantage of producing a graphic record that an

143 See, e.g., National Treasury Employees' Union v. von Raab, No. 86-3833, slip op. at 29 (5th Cir. Apr. 22, 1987) (WESTLAW, CTA database; LEXIS, Genfed library, Usapp File) (EMIT may not be sufficiently reliable without GC/MS confirmation); Higgs v. Wilson, 616 F. Supp. 226 (W.D. Ky. 1985) (upholding injunction of testing, finding tests sufficiently unreliable to establish likelihood of violation of plaintiff's due process rights); Kane v. Fair, 33 Grim. L. Rep. (BNA) 2492 (Mass. Super. 1983) (stating that EMIT can only be used as evidence if confirmed by another method of analysis). See also Pella v. Adams, 638 F. Supp. 94, 97 (D. Nev. 1986) (denying summary judgment on due process claim that single EMIT test unreliable); Anable v. Ford, 653 F. Supp. 22, 44 (W.D. Ark. 1985) (finding the EMIT test insufficiently "probative of the guilt or innocence of the student to justify its use"); Storms v. Coughlin, 600 F. Supp. 1214, 1222 (S.D.N.Y. 1984) (substantial question of fact exists regarding accuracy of EMIT). Cf. 49 C.F.R. $§ 219.307$ (b) (1986) (immunoassay not acceptable to Federal Railroad Administration as confirmatory test).

144 See infra notes 165-69 and accompanying text. See also Exec. Order. No. $12,564 \S 1$ (c), 3 C.F.R. 224 (1987) ("Persons who use illegal drugs are not suitable for Federal employment.").

${ }^{145}$ See Courtroom Toxicology, supra note 128 , at $\S 30.10[3]$.

148 See Peranzo, 608 F. Supp. at 1514 n.16.

147 See Confirmation, supra note 136, at 498 (TLC actually showed advantage over GC/MS); Pe, Use of Descending Thin Layer Chromatography for Identification of Cannabinoids, 37 BuLL. ON NARCotics 83, 85 (1985) (a TLC method produced results "comparable to the results obtained by GC"). See also Wykoff v. Resig, $613 \mathrm{~F}$. Supp. 1504, 1512 (N.D. Ind. 1985) (court accepts TLC as sufficiently reliable confirmation test).

148 See Courtroom Toxicology, supra note 128, at § 21.10. See also Rajananda, Nair \& Navaratnam, An Evalutation of TLC Systems for Opiate Analysis, 37 Bull. ON Narcotics 35, 38-44 (1985) (finding disparity in effectiveness of different TLC systems for detecting opiates).

${ }_{149}$ See Stille, supra note 4 , at 23 , col. 4 ( $\$ 5$ for screening test, up to $\$ 80$ for "sophisticated confirmation tests"); Comment, supra note 132, at 396 n.60 (MS test for THC metabolite-indicator of marijuana use-costs approximately $\$ 75$, with RIA and GC together approximately \$9).

180 See GC/MS Assays, supra note 134, at 1; Courtroom Toxicology, supra note 128 , at $\S 23.07[1]$. 
independent expert can review. ${ }^{151}$ But even GC/MS is not free from error. It is known to misidentify some compounds, and the high level of training required to perform the test makes it all the more likely that a misidentification will occur. ${ }^{152}$

Given the probability of false positives from immunoassays as screening tests, failure to confirm such a result through a separate analytic technique presents an intolerable chance of falsely indicating illegal drug use by an employee. A positive result from one of these tests is tantamount to an accusation by an informer who is known to lie a significant percentage of the time. Due process would seem to require more evidence than that before an employee is terminated. Specifically, the high degree of reliability desired in such cases requires confirmation of positive immunoassay results by chromatographic means (as long as no equally accurate methods have been developed) before final action can be taken against any employee. ${ }^{153}$ Furthermore, any test used as the basis for a personnel action must be done in a lab meeting preset standards for employee training and quality control. ${ }^{154}$ Absent these conditions, the "risk of error" branch of the Mathews test carries almost dispositive weight.

\section{Interpretation of a True Positive Result}

Even if the initial positive result is accurate, or, accurate or not, is confirmed by further testing, this does not necessarily mean the employee is the menace to the public safety, or workplace safety, or efficiency that the test is meant to detect. Traces of marijuana remain in urine for weeks, so it is possible that a positive result for marijuana indicates off-duty use not affecting the employee's job performance. ${ }^{155}$

151 See McBay, Problems in Testing for Abused Drugs, 255 J. A.M.A. 39, 40 (1986) (letter to the editor).

152 See CourTroom Toxicology, supra note 128 , at $\$ 23.08$ (GG/MS requires a highly trained operator for reliable results); Confirmation, supra note 136, at 499 (GC/MS erroneously found THC in two samples out of 30 tested, perhaps because of sensitivity of instruments); Comment, supra note 132, at 398 (describing possible laboratory problems affecting reliability of test).

${ }_{103}$ Cf. 49 C.F.R. $\S 219.307$ (b) (1986) (Federal Railroad Administration effectively requires such confirmation by mandating retesting by a "method capable of providing quantitative data specific to the drug (or metabolite(s)) detected").

${ }_{154}$ See Exec. Order No. 12,564, 3 C.F.R. 224 (1987) (requiring agencies to conduct their testing programs subject to technical guidelines promulgated by the Secretary of Health and Human Services). A house of the New Jersey legislature passed a bill providing, inter alia, that employees tested for drugs may get their test results checked by state-approved medical facilities. See N.J. Assembly Passes Law Allowing Drug Testing of Most Employees, 25 Gov't Empl. Rel. Rep. (BNA) 41 (Jan. 12, 1987).

${ }_{160}$ See Dackis, Pottash, Annitto \& Gold, Persistence of Urinary Marijuana Levels After Supervised Abstinence, 139 AM. J. Psychiatry 1196, 1197 (1982) [here- 
Although a blood test could confirm intoxication, no urine test can show how recently marijuana was ingested. ${ }^{156}$ On the other hand, there is speculation that the body retains the psychoactive ingredient of marijuana long after the last inhalation, possibly causing impairment for days after the user notices any effect. ${ }^{157}$ A test of pilots in a flight simulator showed impairment even twenty-four hours after smoking marijuana; one of the pilots, who reported no awareness of any intoxication, missed the runway completely. ${ }^{138}$

Notwithstanding the disturbing implications of this experiment, medical findings concerning the duration of the effects of marijuana use remain inconclusive. ${ }^{158}$ A positive urinalysis result, therefore, is not conclusive proof that an employee is impaired on the job. Research indicates that urinalysis also cannot discern active smoking of marijuana and hashish from passive inhalation, or the inhalation of smoke from the use of the drug by others. ${ }^{160}$ An employee could become impaired through passive inhalation, ${ }^{161}$ and a positive test for marijuana would not show why she was impaired. But involuntary exposure to the drug hardly seems to justify discharge or discipline. A nonsmoker can test positive through EMIT several days after passive inhalation. ${ }^{\mathbf{1 6 2}}$ Similarly, ingestion of poppy seeds in food can cause one to test positive for morphine or heroin, even when TLC or GC/MS is used. ${ }^{163}$ These con-

inafter Urinary Marijuana Levels] ("Urinary excretion of cannabinoids persists for roughly 3 weeks after supervised abstinence . . . ."); Comment, supra note 132, at 397 (Although THC, the intoxicating ingredient in marijuana, is present only during the intoxicated state, the THC metabolite, a by-product of $\mathrm{THC}$, remains in the body for an extended period.).

${ }^{158}$ See, e.g., 49 C.F.R. $\S 219.309$ (b)(2) (1986) (the urine test "cannot distinguish between recent use off the job and current impairment"). If a federal railroad employee provides a blood test, it removes the presumption of impairment that would result from a positive urine test. See id.

187 See Urinary Marijuana Levels, supra note 155, at 1197.

${ }^{108}$ Yesavage, Leirer, Denari \& Hollister, Carry-Over Effects of Marijuana Intoxication on Aircraft Pilot Performance: A Preliminary Report, 142 AM. J. PsYCHIATRY 1325, 1328 (1985).

${ }^{169}$ Id. at 1328-29 (arguing that further research is needed to define the point after smoking THC at which impairment ceases).

${ }^{160}$ See Morland, Bugge, Skuterud, Steen, Wethe \& Kjeldsen, Cannabinoids in Blood and Urine After Passive Inhalation of Cannabis Smoke. $30 \mathrm{~J}$. Forensic ScI. 997, 1001 (1985) [hereinafter Passive Inhalation I] (positive EMIT urinalysis results three days after passive inhalation). See also Zeidenberg, Bourdon \& Nahas, Marijuana Intoxication by Passive Inhalation: Documentation by Detection of Urinary Metabolites, 134 AM. J. Psychiatry 76, 77 (1977) [hereinafter Passive Inhalation II] (cannabinoids found in passive inhaler). But see Perez-Reyes, Reply to Passive Inhalation of Marijuana Smoke, 250 J. A.M.A. 898 (1983) (letter) (challenging Zeidenberg's experimental method).

161 See Passive Inhalation II, supra note 160, at 77.

162 See id.; Passive Inhalation I, supra note 160, at 1001.

${ }^{163}$ See, e.g., Bjerver, Jonsson, Nilsson, Schuberth \& Schuberth, Morphine Intake 
siderations militate against attributing great reliability to the drug urinalysis techniques presently available.

\section{B. The Employee's Interest}

An employee whose urinalysis indicates illegal drug use has several interests that would be irreparably damaged if she were fired, even if she were reinstated on a post-termination finding that the urinalysis result was false. Primarily, she has a property interest in her continued income, but income is not the only thing at stake. The employee also has a strong interest in "the continuation of the opportunity to perform meaningful and fulfilling work."164 The importance of these interests implies a need for full determination of facts before the employee is discharged.

The fact-finding effort should be careful and serious. A deep stigma, especially among employers, still attaches to people branded as drug users. ${ }^{165}$ An employee discharged as the result of a drug test could find herself unable to find work elsewhere because of the circumstances of her discharge. ${ }^{186}$ Accordingly, testing under Executive Order $12,564,{ }^{167}$ which purports to set an example for other employers, should be accompanied by stringent fact-finding. ${ }^{168}$ If a person labelled

from Poppy Seed Food, 34 J. Pharmacy \& Pharmacology 798, 800 (1982) (finding that the poppy seeds in a commercially available food contained 5 milligrams of morphine, an amount insufficient to cause noticeable effects, but sufficient to create positive test results even when TLC is used); Fritschi \& Prescott, Morphine Levels in Urine Subsequent to Poppy Seed Consumption, 27 Forensic SCI. INT'L 111, 116 (1985) (differentiation of heroin users from poppy seed eaters apparently requires GC/MS detection of heroin itself or acetylmorphine in urine).

164 Brief of AFSCME, amicus curiae, at 12, Gleveland Board of Education v. Loudermill, 470 U.S. 532 (1985) (No. 83-6392).

1es See J. Rublowsky, The Stoned Age: A History of Drugs in America 198-99 (1974) (likening the demonization of drug addicts in America to the treatment of Jews in Nazi Germany). See also Nelson, Drug Abusers on the Job, 23 J. OccupATIONAL MED. 403, 405 (1981) ("The highly negative and prejudicial image of dope fiends and reefer smokers of the 1940's still prevails in many board rooms.").

${ }_{160}$ See Loudermill, 470 U.S. at 543, quoted supra at text accompanying note 96; see also Jones v. McKenzie, 628 F. Supp. 1500, 1505 (D.D.C. 1986) (finding of drug use by an employee will remain on file for automatic publication to any prospective employer).

167 See supra notes 64-68 and accompanying text.

${ }_{188}$ The order provides that, before a testing program can begin, employees must receive sixty days' advance notice and an opportunity to submit medical documentation supporting the legitimate use of specific drugs, or voluntarily to obtain assistance for a drug problem. In addition, each agency's program must include procedures for retesting, confidentiality, and the retention of test records and specimens. 3 C.F.R. 224 (1987). The procedural requirements discussed infra notes 177-203 and accompanying text apply to the way in which federal agencies should implement the order and state agencies should implement their own drug testing programs. The Department of Health and Human Services announced government-wide guidelines for implementing 
an illegal drug user is "not suitable for [f]ederal employment,"169 other employers, following the federal government's example, may be reluctant to hire her.

An employee who does not use drugs certainly has an interest in avoiding this stigma. But it is also possible for a real drug user, even an addict, to be a completely stable worker. ${ }^{170}$ Since urinalysis "indicates nothing more than the presence or absence of drugs[,] . . . provides no information about the pattern of use[,] and cannot distinguish between the occasional user unfortunate enough to have indulged just before the test and the chronic abuser,"171 an employee who is never impaired on the job could erroneously be held responsible for being part of the "drug problem." Such a branding arguably infringes a liberty interest. ${ }^{172}$

This is not to suggest that a properly-confirmed true-positive urinalysis result cannot raise a presumption that the employee in question is impaired in the performance of her duties. Especially if the detected drug is an addictive one, there is at least a substantial possibility that its use will affect the employee's job performance. ${ }^{173}$ However, the very real possibility that such drug use has no adverse effect on the particular employee's performance means that the presumption should be rebuttable. If the employee can show that she has never displayed the poor productivity, unsafe work habits, and other bad traits against which employee drug testing is meant to protect, ${ }^{174}$ lumping her together with those who do exhibit such traits may well be an arbitrary deprivation of her liberty interest in her reputation.

The stigma accompanying a drug-based firing is not the only consequence of drug testing that can affect an employee's liberty. Liberty is also affected when the employee has a choice between termination and

the Order in February 1987. Notable among these guidelines was a requirement of GC/MS confirmation of any positive test result. See Alcohol, DRUG ABUSE AND Mental Health Administration, Scientific and Technical Guidelines for Drug Testing Programs (1987), reprinted in 9A Lab. Rel. Rep (BNA) (Indiv. Empl. Rts. Manual) § 595, at 751, 755 (1987).

100 Exec. Order No. 12,564, § 1(c), 3 C.F.R. 224, 225 (1987).

170 See Nelson, supra note 165 , at 403 (citing documentation of long-term heroin addicts with long stable work histories); Redfield, Drugs in the Workplace-Substituting Sense for Sensationalism, 63 AM. J. PUB. HeALTH 1064, 1065 (1973) (suggesting that the sole practical approach is to consider only those employees whose drug use impairs their health, work performance, attendance or behavior as being "drug problems").

171 Lewy, Preemployment Qualificative Urine Toxicology Screening, 25 J. Occupational Med. 579, 579 (1983).

172 See supra notes 98-111 and accompanying text.

173 See supra notes $123-24$ and accompanying text.

174 See Exec. Order No. 12,564, preamble, 3 C.F.R. 224, 224 (1987). 
entering counselling or medical treatment as part of an employee assistance program ("EAP"). ${ }^{175}$ Requiring a person to undergo such treatment invades her personal autonomy, especially when the counselling or treatment is unnecessary. ${ }^{178}$ Requiring her to enter such a program as a condition of keeping her job, without first affording her procedural protections, forces her to choose between losing her job and accepting a deprivation of liberty without due process of law. The Supreme Court has held that the government cannot condition public employment on the surrender of a constitutional right. ${ }^{177}$ Thus, before an employer can force an employee to choose between termination and rehabilitation, the Constitution requires some kind of fact-finding procedure to confirm that the employee does, in fact, require rehabilitation. As we shall see below, once there has been a procedurally adequate finding that an employee has used drugs, the option of undergoing treatment can be an indispensable method of determining whether the employee is suitable for continued employment.

We have seen that there are several employee interests that require procedural safeguards to protect them from unjustified infringement. The following section proposes specific measures that are necessary to protect these interests adequately. It also argues that the phenomenon of drug testing calls for the courts to broaden their analysis of what process is due before the government deprives its employees of these interests.

\section{Proposed Minimum Requirements of Procedural Due Process}

This discussion of specific procedural requirements focuses on the period after a positive initial test result has been obtained. To avoid stigmatizing an employee undeservedly, the employer should keep positive test results strictly confidential until a final determination has been made as to discipline. Since an employee's legal status does not change except with discharge, it may be that, under Paul $v$. Davis, ${ }^{178}$ no notice or hearing is constitutionally required before the result is published. ${ }^{179}$

178 See infra notes 191-94 and accompanying text.

176 See Stille, supra note 4, at 24, cols. 2,3 (employee tested positive for cocaine forced to spend 28 days in clinic despite several negative follow-up tests and statement of doctors at clinic that no rehabilitation was needed).

177 See, e.g., Keyishian v. Board of Regents, 385 U.S. 589, 605-06 (1967) (freedom of association); $c f$. Thomas v. Review Board, 450 U.S. 707 (1981) (government cannot condition a public benefit, unemployment compensation, upon the surrender of a constitutional right, free exercise of religion).

178424 U.S. 693 (1976); see supra text accompanying notes 101-03.

179 "Publish" in this context has the same meaning as the related concept of publication in libel law, that is, to make known to third persons. BLACK's LAw Diction- 
Alternatively, it can be argued that Paul was an anomaly and inconsistent with previous cases ${ }^{\mathbf{1 8 0}}$ and that an employee should have the same kind of hearing before her positive result is announced as she deserves before being disciplined or fired.

Because of the uncertain reliability of the testing methods and the relative weight of the employee's interests that are at stake, the aforementioned hearing should include a full opportunity for the employee to present evidence. The employee should at least have a chance to show the absence of on-the-job impairment. This will usually be impossible to show conclusively, because of the difficulty of proving a negative. Nonetheless, it may be possible to convince an administrative decisionmaker that the employee's use of, for example, marijuana, was an isolated instance that did not affect her work performance. In this situation, the employee has grounds to argue that termination, or even harsh discipline, is unnecessary. ${ }^{\mathbf{1 8 1}}$

In most cases, the real value of an evidentiary hearing is in allowing the employee to impeach the accuracy of the test result. There is judicial support for the argument that due process requires the employer to preserve the urine specimen for the employee to have retested if she so chooses. ${ }^{182}$ Submission of a new specimen some time after the original test would be insufficient to rebut the original test result because the absence of drug metabolites from the second sample could indicate merely that the employee stopped taking drugs until retesting. Therefore, there is value in preserving the original specimen for retesting.

The requirement of a pretermination hearing does not mean that bus drivers who test positive for drug use must remain on duty throughout the administrative process. But even when public safety argues for an employee's removal with a minimum of delay, suspension or transfer to a less sensitive position pending a final determination would be more consistent with due process than would summary discharge. ${ }^{183}$

On the issue of whether the employee actually used drugs, the

ARY 1105 (5th ed. 1979).

180 See supra note 104.

181 See Kruger v. Department of Justice, 32 M.S.P.B. 71, 77 (1987) (discharge based on detected marijuana use reduced to sixty-day suspension according to the policy underlying Executive Order 12,564).

182 See Banks v. FAA, 687 F.2d 92, 95 (5th Cir. 1982).

18s See Jones v. McKenzie, 628 F. Supp. 1500, 1507 (D.D.C. 1986); see also Arnett v. Kennedy, 416 U.S. 134, 194 (1974) (White J., concurring in part and dissenting in part) (suspension with pay would obviate the problems caused by delay in the termination of a potentially disruptive employee). 
standard of proof at the hearing should be high, notwithstanding a tendency to demand a relatively low measure of proof in the private sector. Arbitrators are often faced with challenges to the discharge of employees based on contractual prohibitions of drug use. Many arbitrators in drug-related discipline cases merely require that they be "convinced" that the grievant in fact used drugs, usually meaning by a preponderance of the evidence. ${ }^{184}$ But some interpret this standard as being the same as "clear and convincing evidence" in other contexts. ${ }^{185}$ The standard can be somewhat lower when there will be an immediate public safety risk if the employee is in fact impaired. ${ }^{188}$ This arbitration approach, dealing mainly with private employers, does not consider the exceptional relationship between a government agency and its employees. The relation of the government to an individual has implications for personal liberty that are absent from the private-sector employment relationship. ${ }^{187}$ The special nature of the government-individual relationship means that the government must act with a higher degree of certainty than does a private employer when it deprives a citizen of a state-created interest.

The degree of certainty must be especially high when the deprivation is based on a finding that the employee has committed an illegal act. ${ }^{188}$ Accordingly, a public employer should bear the burden of proving drug use by a standard that at least approaches "beyond a reasonable doubt." A urinalysis result can meet this standard only if accompanied by recorded quantitative evidence, such as a chromatograph or

184 See T. Denenberg \& R. Denenberg, supra note 142 , at 54-56. See also Kroger Co. v. BCTWU Local No. 372-A, 86-2 Lab. Arb. Awards (GCH) II 8407 (June 19, 1986) (Wren, Arb.) (Where the grievant was fired for using cocaine on the job, the arbitrator declined to apply a standard of proof higher than to a preponderence because use of cocaine was not malum in se. The arbitrator distinguished this situation from those in which an employee discharged, for example, for dishonesty or theft would have difficulty finding other employment. This may have been an unrealistic view of the position of an announced drug user in the job market.).

${ }^{185}$ Chase Bag Co. v. Amalgamated Glothing and Textile Workers Local 377T, 87-1 Lab. Arb. Awards (GCH) if 8001 (May 24, 1986) (Strasshofer, Arb.).

186 Washington Metro. Area Transit Auth. v. Local 922, Int'l Bhd. of Teamsters, 82 Lab. Arb. (BNA) 150, 152 (December 19, 1983) (Bernhardt, Arb.).

187 See Reich, supra note 89, at 785.

188 See Jenkins v. McKeithen, 395 U.S. 411, 427-31 (1969) (Plaintiffs stated a cause of action for a due process violation where administrative board made findings of criminal guilt without affording the individuals in question the full right to cross-examine witnesses. The Court remanded to the district court to determine whether due process required that all the procedural protections available to a criminal defendant be present in the administrative proceeding.); Hannah v. Larche, 363 U.S. 420,488 (1960) (Frankfurter, J., concurring in the result) (if administrative body were accusing individuals of illegal activity, "the rigorous protections relevant to criminal prosecutions might well be the controlling starting point" for assessing the adequacy of that body's procedures). 
mass spectrum, showing compounds in the urine with characteristics unique to the particular drug in question. Along with the chance to retest the urine specimen itself, ${ }^{189}$ the employee must have the opportunity to inquire into the testing procedure to evaluate whether proper laboratory techniques were used. ${ }^{190}$

The above procedure only applies to proof of past drug use. To avoid merely punitive use of drug testing, due process requires a demonstration that the employee will continue to be a threat to the employer's legitimate interests. Proving that the employee used drugs does not necessarily mean that she will be such a threat. But even if proof of drug use raises a presumption of continued impairment, an employee must have adequate opportunity to rebut this presumption. We will now examine a procedural requirement that would serve the purposes of the due process guarantee while respecting both the public and individual interests that employee drug testing affects.

The federal government and many private businesses provide programs for employees to get counselling or other treatment for chemical dependency. ${ }^{191}$ These employee assistance programs, or EAPs, have been found to save employers money by improving productivity and employee morale. Instead of firing an employee who has a drug problem and hiring an untrained replacement, the business gets back the experienced employee after rehabilitation. ${ }^{192}$ Arbitrators sometimes hold that when an employer has an EAP, an employee found to be using drugs must have the option of entering rehabilitation rather than being dismissed. ${ }^{103}$

Such a requirement with regard to public employees is sound public policy. It serves the agency's, and thus the public's, interest in retaining experienced personnel, and it furthers the employee's interests

189 See supra note 182 and accompanying text.

100 See Banks v. FAA, 687 F.2d 92, 94 (5th Cir. 1982) (due process requires greater opportunity to inquire into testing procedures and cross-examine laboratory director when urinalysis results were the only evidence leading to discharges). It may not be necessary to afford an employee the most stringent procedural safeguards when she has been criminally indicted on drug charges arising from the same incident or circumstances that motivated the employer to test; $c f$. Hatteras v. Southwestern Bell Tel. Co., 774 F.2d 1341, 1344 (5th Cir. 1985) (no pretermination hearing required where telephone service was terminated after customer-operator of an escort service-was indicted for prostitution).

191 See Lewis \& Lewis, Preventive Approaches: Programs in Business and Industry in DRUGS AND Alcohol 79, 80 (A. Carmi \& S. Schneider, eds. 1986); Nelson, supra note 165, at 405. See also Exec. Order No. 12,564, 3 C.F.R. 224, 225 (1987).

192 See T. Denenberg \& R. Denenberg, supra note 142, at 35-36; Nolan, $M u-$ tual Respect, Understanding Combat Substance Abuse, DATA MGMT., Dec. 1985, at $18,19$.

193 See, e.g., Washington Metro. Area Transit Auth. v. Local 922, Int'l Bhd. of Teamsters, 62 Lab. Arb. (BNA) 150, 152 (Dec. 19, 1983) (Bernhardt, Arb.). 
by allowing her both to keep her job and lose her drug dependency. Moreover, the EAP option reduces the danger that drug testing will be used merely as an instrument of punishment.

Legislation can make an EAP option mandatory. For example, the New Jersey legislature recently passed a bill requiring public employers who do drug testing to grant a leave of absence for rehabilitation to an employee whose test results are positive. ${ }^{194}$ But a statutory requirement is, obviously, not necessarily a constitutional one. Is a public employer required to offer an employee the opportunity for rehabilitation as a matter of constitutional due process?

Analyzed by the traditional "root requirement" of procedural due process, notice and hearing, ${ }^{198}$ the answer appears to be a clear "no." However, proving the employee's unwillingness or inability to stop taking drugs is part of showing her unfitness for public service. ${ }^{196}$ Whether the burden to prove or disprove this unfitness is on the employer or employee, the best procedure for meeting the burden is an EAP.

Since drug addiction is a "handicap" under the Rehabilitation Act ${ }^{197}$ and various state handicap discrimination statutes, ${ }^{198}$ employers have a duty of reasonable accommodation to the addict's problem. ${ }^{189}$ This statute-based duty probably requires employers to provide EAP options. ${ }^{200}$ An expansive interpretation of the due process protection may mean that the Constitution requires the same.

The Supreme Court has long recognized that procedural due process requirements are flexible, adapting over time to specific situations. ${ }^{201}$ Commentators have argued that "[d]ue process need be flexible

194 See supra note 154.

198 Cleveland Bd. of Educ. v. Loudermill, 470 U.S. 532, 542 (1985) (quoting Boddie v. Connecticut, 401 U.S. 371, 379 (1971)).

${ }^{198}$ Executive Order 12,564, aimed at eradicating drug use from the federal workplace, recognizes the importance of such proof in determining who is unsuitable for continued employment. See Exec. Order No. 12,564, § 5(d), 3 C.F.R. 224, 227 (1987) (only those employees who refuse to enter rehabilitation or who resume drug use after an initial detection are to be terminated).

19229 U.S.C. $\$ \S 701-796$ (1982 \& Supp. III 1985). See, e.g., Davis v. Bucher, 451 F. Supp. 791 (E.D. Pa. 1978) (drug addiction is subject to Act's protection).

${ }_{108}$ See Geidt, Drug and Alcohol Abuse in the Work Place: Balancing Employer and Employee Rights, 11 EMPLOYEE REL. L.J. 181, 184 (1986) (listing statutes).

100 See 29 C.F.R. § 1613.702(f) (1986). See also Geidt, supra note 198, at 185. 200 See Geidt, supra note 198 , at 194.

201 See L. TRIBE, supra note 85 , at 539 ("[G]onsideration of what procedures due process may require under any given set of circumstances must begin with a determination of the precise nature of the government function involved as well as of the private interest that has been affected by governmental action." (citing Cafeteria \& Restaurant Workers Local 473 v. McElroy, 367 U.S. 886, 895 (1961))); Joint Anti-Fascist Refugee Comm. v. McGrath, 341 U.S. 123, 161-63 (1951) (Frankfurter, J., concurring) (in 
mainly in terms of the specific procedures that courts require. The values that the clause represents, on the other hand, are more enduring. Once the values are discerned, a court's task is to assess the manner in which these values may best be realized." 202 Do the values that the due process clauses represent demand that a public employee not be deprived of her job without an opportunity to show she can stay off drugs?

One of the dominant purposes of procedural due process is reducing the risk of factual error when deciding whether a deprivation is justified. ${ }^{203}$ If the purpose of detecting employee drug use is to identify those employees who pose a risk to public safety or the integrity of the employing agency, the EAP option helps considerably to realize this goal. Once an employee has recovered from a drug habit or other pattern of abuse, she has shown that she is fit to return to duty. On the other hand, if the employee were simply fired, the employing agency would have no way of knowing whether or not she could have been salvaged as an effective member of the workforce. Discharge without the option of rehabilitation is not the best way to determine who is permanently unsuitable for public service.

The EAP option is an appropriate procedural requirement whether or not the initial proof of drug use raises a presumption of future impairment. If there is no such presumption, an EAP option is the best way for the employer to show the employee's unwillingness or inability to stop using drugs. And if the employee is subject to such a presumption, the EAP option is necessary because it is the only effective "hearing" by which she can overcome the presumption.

\section{ConClusion}

While the rulings of various courts differ as to the circumstances under which public employers may and may not test their employees for drug use, it is likely that many categories of public employees, especially those whose jobs directly affect public safety, will remain subject to drug urinalysis testing. The prospect of losing one's job as the result of being identified as an illegal drug user jeopardizes some of an individual's most fundamental interests: income security, the opportunity

the conditions prevailing during the cold war period, designating an organization as subversive presented an exceptional hardship to the organization requiring special procedures before the hardship was imposed).

${ }_{202}$ Redish \& Marshall, Adjudicatory Independence and the Values of Procedural Due Process, 95 YALE L.J. 455, 474 (1986).

${ }_{203}$ See, e.g., Goldberg v. Kelly, 397 U.S. 254, 266 (1970) (pretermination hearing serves to prevent erroneous removal of benefits from deserving recipients). 
for fulfilling work, and the liberty to move freely in the job market.

Because of the weight of these interests, the judicial assessment of drug testing in prisoner discipline cases ${ }^{204}$ is not applicable to the public employment context. Such analysis is not sensitive enough to the questionable reliability of the scientific methods currently in use. A careful balancing of the government interests involved against the individual interests discounted by the risk of error, as prescribed in $\mathrm{Ma}$ thews $v$. Eldridge, ${ }^{205}$ suggests that stringent confirmation requirements must be met before any employment action begins against an employee testing positive. Due process allows no final termination before the employee has had a full opportunity to challenge the test results.

Finally, because of the unprecedented nature of the government effort to detect drug abuse among public employees, the traditional concept of an "opportunity to be heard" should be expanded. Requiring an employer to disprove, or offering an employee the chance to prove, her willingness to change, before dismissing her as unsuitable for public employment, advances the notions of factual certainty and fairness that the constitutional guarantee of due process exists to serve. 